\title{
A Nietzschean Justification of Legal Realism
}

\author{
Keith William Diener* \\ George Washington University School of Business Professorial Lecturer of Law, George Washington University Law \\ School
}

\begin{abstract}
This essay examines the thought of Friedrich Wilhelm Nietzsche, the advances made by the legal realist jurisprudential movement, and correlates the two. It concludes that legal realism is entailed in Nietzschean metaphysics, and particularly his doctrine of will to power. Legal realism is determined to be a symptom of the more comprehensive Nietzschean principle of power. A preliminary framework for a Nietzschean justification of legal realism is developed.
\end{abstract}

Keywords: Ethics, Experimental Ethics, Jurisprudence, Legal Realism, Nietzsche, Will to Power.

\section{INTRODUCTION}

The German philosopher, Fr iedrich Nietzsche wrote in the latter part of the nineteenth century, and is perhaps most famous for his critique of religious morality and controversial assertion that God is dead. Nietzsche's lesser known works and particularly his posthumously published Will to Power, set forth several of the basic tenets of legal realism, a theoretical movement of jurisprudence which began also in the latter part of the nineteenth century. This essay examines the relationship between Nietzsche's philosophy and le gal realism. It ske tches a preliminary framework for a Nietzschean justification of legal realism. This paper is structured in four parts. Part o ne examines excerpts of Nietzsche's works, and provides a detailed explication of the central tenets of his philosophy. Part two sets forth the central underlying principles of legal realism while simultaneously examining several of the most important contributors to the movement. Part th ree presents a preliminary framework for the position that Nietzsche's philosophy may be used as a justification of legal realism. The final part is a conclusion.

\section{PART I: THE THOUGHT OF FRIEDRICH NIETZSCHE}

Friedrich Wilhelm Nietzsche was born on October 15, 1844 , and was raised in the province of Saxony, located in contemporary eastern Germany [1]. He was the son of a Lutheran pastor, and struggled throughout his life with a disdain for his religious upbringing [1]. In his youth, Nietzsche excelled scholastically, so much, in fact, that he achieved his first professorship at the Uni versity of Basel, Switzerland at the age of twenty-four [1]. Ni etzsche soon therea fter began publishing with his first book, The Birth of Tragedy, which was released in 1872 [1]. Over the subsequent seventeen years, Nietzsche published several works despite recurrent

\footnotetext{
*Address correspondence to this author at the Geor ge Washington University School of Business, Funger Hall, Suite 615, 2201 G. St N.W., Washington D.C., 20052; Tel: 703-869-7176; Fax: 888-202-8896;

E-mails: Kdiener1@gwu.edu; kdiener1@law.gwu.edu
}

medical problems that are typically attributed to his battle with syphilis [1]. Nietzsche's academic career ended at approximately forty-four when his health deteriorated to a point of non-recovery [1]. He then passed away in the year 1900 [1]. Nietzsche's sister preserved several of his papers and, after his death, published them under the title The Will to Power [1]. Although these papers were written by Nietzsche, they were not in final form, and were pieced together to present a somewhat coherent work [1]. Nietzsche's writings addressed $a b$ road spectrum of topics; his works were written in such a manner as to make analysis of his ideas difficult. Despite this complexity of thought which at times is seemingly contradictory even of itself, the following discussion attempts first, to set fo rth several of the major tenets of Nietzschean thought, and then to analyze the Nietzschean view of society and the individual.

\section{(A) Tenets of Nietzschean Thought}

The writings of Friedrich Nietzsche lay the foundation for much of what is currently considered to be postmodernist thought. Nietzsche is con cerned with moving beyond traditional ideological positions, including a move beyond Christian morality and the traditional conceptions of go od and evil. In s o doing, Nietzsche creates his own metaphysical enterprise, which overcomes traditional dichotomies, and portrays reality as will to power. His descriptive and interactive methodology sparsely entails fundamental principles, but instead spends considerable efforts discrediting previously accepted principles. Nevertheless, Nietzsche often experiments with his conception of will to power as an allencompassing force of nat ure and humanity. Nietzsche's conception of will to power is unique insofar as it deemphasizes power as dominion over another, and extends its meaning to entail knowledge, physics, moralities, science, nature, and even life and the world more generally [1-3]. As Nietzsche explains, "This world is the will to power- and nothing besides! And you yourselves are also this will to power- and nothing besides!" [3] (p. 550). The broad scope of his doctrine of will to power is the basis for Nietzsc he's new metaphysics. As a co nstruct that permeates all, will to power provides a new means of understanding and analyzing 
reality while simultaneously moving beyond former ideologies.

Nietzsche's relentless questioning of previous conceptions of morality, and movement away fro $\mathrm{m}$ fundamental principles is apparent in his description of "every great philosophy" as a mere instrument of its author [4] (pp. 10-11). As Nietzsche postulates: "Indeed, to understand how the abstrusest metaphysical assertions of a philosopher have been arrived at, it is always well (and wise) to first ask oneself: "what morality do they (or does he-) aim at?" [4] (p. 11). In this passage, Nietzsche describes a position of skepticism towards previous philosophies. He questions the motives and intentions of philosophers. He emphasizes the various impulses that may lead one to create such knowledge, and how such impulses are often a symptom of the master morality: another key component of Nietzschean thought [4] (pp. 11-12).

The master-slave moralities and overman are integral components of Nietzsche's attack on Christian and philosophical ideologies. The master morality, for Nietzsche, is the creator of a value-system. The master morality creates moral designations such as "good" and "bad." Those who impose the master morality become the ruling group which imposes values on others. Those who have values imposed on them are a creat ure of the slave morality. The slave morality includes those who are "the abused, the oppressed, the suffering, the unemancipated, the weary, and those uncertain of themselves...." [4] (p. 230). The slave is s ubjected to the morality created by the master, and is su spicious of it [4 ] (pp. 230-232). In order to overcome such oppression, one must develop one's own value system - and such is the task of the overman. As Nietzsche explains: "The word "overman" as the desi gnation of a type of supreme achievement...has been understood almost everywhere with the utmost innocence in the sense of those very values whose opposite Zarathustra was meant to represent- that is, as an 'idealistic' type of a higher kind of man, half 'saint,' half 'genius'" [5] (p. 261). In order to overcome the master-slave moralities of Christianity and other philosophies, one must overcome the overman by developing one's own system of values.

In overcoming the overman, one puts oneself in the position of a master. The master is reflected in the circularity of Nietzsche's imperative to ove rcome the overman. As the creator of the imperative of the overman, Nietzsche imposes his value-system on the reader: a value-system erected through will to power. Just as Nietzsche critiques other philosophers for imposing their values, morality, science, desires, and prejudices through their philosophies, Nietzsche cannot escape the same criticism. Despite Nietzsche's efforts to move beyond good and evil, he replaces the prior conceptions with new terminology, new im peratives, and a new fundamental principle of will to power. In order to overcome the overman, one is placed in a position of embracing the Nietzschean imperative or ignoring it entirely.

\section{(B) Society and Individual}

Friedrich Nietzsche asserts that will to power exists within the relationship between the state and the individual, and within the relationship between separate states. At times, Nietzsche examines the relations hip between the state a nd the individual as one similar to the relationship between the master and slave [3] (pp. 382-418). The slave is encumbered by his obligations to society, suspicious of it, and controlled by it. The state is unencumbered by such restraints as a ccountability, and is capable of participating in actions that an individual would find abhorrent. The master and slave relationship is apparent, according to Nietzsche, within the relationship between the state and the individual.

The will to power may be described from both internal and external vantages. The internal is the control and dominance of the state over its populace. This control is implemented by police, punishment, commerce, and law. The individuals are always subject to what Nietzsche refers to as an "organized immorality" on an internal basis [3] (p. 382). From the external vantage, the state wills its power th rough battle, conquest, and war. The state p articipates in atrocities which are seemingly legitimized by virtue of the master morality of the state. As Nietzsch e explains, the state participates in a variety of things that an individual would find reprehensible: "[t]hrough division of responsibility, of command, and of execution. Through the interposition of the virtues of obedience, duty, patriotism, and loyalty. Through upholding pride, severity, strength, hatred, revenge, -in short, all typical characteristics tha $t$ contradict the herd type" [3] (pp. 382-383). This conception of the "herd" recurs throughout Nietzsche's works, and is often ass ociated with the Christian slave, but more aptly defined as anyone who would give up his or her will to po wer [3-6]. The populace of a state may in many ways be considered a "herd" which abides by the rules, laws, and customs of a so ciety, often without questioning their utility or moral value. This supposition is supported by Nietzsche's assertion that "[e]verything a man does in service to his state is contrary to his nature" [3] (p. 383 ), and thus is not an act of freedom - of will to power. The "organized immorality" of the state manifests the will to power from both internal and external vantages [3] (p. 382).

Nietzsche addresses the division of labor, and how motivation for power impacts one's designation within a society. The division of labor incl udes lawgivers and teache rs, whereas the designations include political parties, the ambitious, and other groups [3] (p. 384). Nietzsche believes that the division of labor between such groups as lawgivers and teachers alleviates any particular group from full responsibility within a society [3] (pp. 383-384). In making these distinctions, Nietzsche is hinting at what is, in contem porary times, referred to as the "tyranny of the majority." The individual is exculpated from blame by the various responsibilities of individuals within a society and the delegation of responsibilities between society's members. This blame is in stead attributed to the tyranny of the state. The motivation for power also plays into this theme. The political parties seek power for the "happiness power provides," yet the a mbitious are willing to give up happiness to ach ieve power, and yet others desire power only so that it does not fall into the hands of those they oppose [3] (p. 384). Power motivations and division of labor and responsibility are functioning aspects of a state's master morality.

Decisionmaking within a state itself is often a question of social judgment which should, according to Nietzsche, be replaced by individual judgment. Appeals to retribution and self-justifications are components of so cial judgment which 
increase the power of a state. Nietzsche cons iders appeals to "common rules and valuations" as an absurd aspect of social judgment, utilized to justify punishment of criminals and to create good c onscience in those who would impose such punishment [3] (p. 385). Nevertheless, these tools are utilized by a court of law i nitiated by the state that imposes standards of measurement, of right and wrong, of illegal and legal [3] (p. 396). Decisionmaking by the state, according to Nietzsche, is a symptom of the herd mentality that should be replaced by individual judgment [3] (p. 403). An individual, for Nietzsche, "derives the values of his acts from himself; because he has to interpret in a quite individual way even the words he has inherited. His interpretation of a formula at least is personal, even if he does not create a form ula: as an interpreter he is still creative" [3] (p. 403). The individual that interprets the formula, the pre-existing ideologies, principles, and rules, is the final arbiter of decision. The relationship between the individual and the state should be rooted in the individual willing to power th e interpretations and formulas that the individual deems appropriate.

The tenets of Nietzsche's philosophy, and particularly his views as to the society and the individual, may be used as a justification of legal realist thought. Before turning to this analysis, however, this essay next sets forth the basic tenets of legal realism.

\section{PART II: LEGAL REALISM}

Legal Realism, as a movement, began gaining momentum in the 1920s, although its beginnings can be traced at least as far back as the 1881 publication of The Common Law by former U.S. Supreme Court Justice, Oliver Wendell Holmes Jr. [7 ]. Holmes describes law as "predictions" of what courts may do whe $\mathrm{n}$ faced with le gal questions [8]. Other major contributors to the foundation of this movement include Jerome Frank and Karl Llewellyn [9]. The major tenets of legal realism, as set forth by Holmes, are displayed in this passage from The Common Law:

"The life of the law has not been logic; it has been experience. The felt necessities of the time, the prevalent moral and political theories, institutions of public policy, avowed or unconscious, even the prejudices which judges share with their fellow-men, have had a good deal more to do than the syllogism in determining the rules by which men shall be governed" [7] (p. 5).

The preceding passage e ncapsulates components of the two basic tenets of the legal realist movement. These tenets notwithstanding, the authors frequently categorized as "realists" or "legal realists" have few other shared values, views, or methods [10] (p. 177). The two tenets of legal realism involve: (1) critiques of legal decisionmaking, and (2) analyzing the indeterminacy of law [10] (p. 178). The following discussion considers each tenet in turn.

\section{(A) Critique of Legal Decisionmaking}

The first tenet of legal realism involves an evaluation of legal decisionmaking, and specifically, judicial and governmental discretion. The realists o ppose the prior formalistic regime claiming that judges do more than merely find the appropriate legal rule, and apply it to the situation. Formalism further contends that, once the appropriate legal rule is found by a judge, coming to a decision is simply a matter of deductive reasoning through syllogisms and si milar logical methods [10] (pp. 178-180). The fo rmer Dean of Harvard Law School, Roscoe Pound, and other realists, term this formalistic method a "mechanical jurisprudence," which is not in practice adhered to [11]. As Justice Holmes explains, the inquiry should be into what courts "likely do in fact" and not what some formalistic theory presupposes they do [8] (pp. 15-24). The realist attack on formalism largely incorporates alternative theories of what judges do in fact, that is to say, how judges make their decisions.

The scope of realist jurisprudence is disputable, although what realists share in common, in terms of their analyses of judicial decisionmaking, is a belief that judges appeal to things outside of legal rules, when coming to decisions. Some realists have even gone so far as to assert that judges act on "hunches," that a judici al decision depends on the "mood" of the judge, or a decision is governed by what the judge had for breakfast [10] (pp. 178-180). The more complex realist theories, however, involve nuanced analyses of judicial appeals to morality, policy, and social scien ces in judicial decisionmaking. Holmes, for exa mple, concludes that judges make decisions based primarily on social policy, but deemphasizes the importance of morality in judicial decisionmaking [8] (pp. 20-21). Holmes, although accounting for the fact that judges appeal to morality in decisionmaking, believes that morality should largely be minimized by judges, who should instead focus on policy. Felix Cohen, on the other hand, more broadly construes the role of judges to include not only considerations of social policy but also considerations of morality [12] (pp. 220-221). Cohen believes that considerations of both morality and policy should be taken into account by judge $s$ when making decisions. Although Cohen and Holmes disagree as to the importance of morality in judicial decision making, both are conside red legal realists. Si milar inconsistencies arise across the spectrum of realist thinkers.

In the realm of international law, several realist theorists ignore considerations of morality and policy altogether, adhering to the belief that legal decisions are made on the basis of power. Dean Acheson, for example, in his Remarks regarding the Cuban quarantine refers to the quarantine as an "ethical distillation" based in a power struggle between states [13]. Acheson does not individuate different aspects of the quarantine as "ethical distillations" but refers to the entire event as such. He does not poin t to a doc ument, such as an executive order, or even a treaty th at constitutes an "ethical distillation" but references the entire crisis in this way [13]. Acheson concludes that the United States participated in the Cuban quarantine not because of international law, rules, or formalism, but instead beca use of a nee $d$ to preserve the power of the state [13]. Similarly, Hans Morgenthau, in his 1948 essay, Politics Among Nations: The Struggle for Power and Peace [14], bases his theory on the premise that "international politics is of necessity power politics," and from this basic premise develops his realist critique of international 
law $[14,15]$ (pp. 95-96). In ad dition to considering legal decisions as base d in "pow er," both Morgenthau and Acheson share the belief that international law is used in a colluded attempt to justify decisions of power politics. As Morgenthau describes:

"Governments...are always anxious to shake off the re straining influence which international law might have upon their international policies, to use international law in stead for the promotion of their national interests, and to evade legal obligations which might be harmful to them. They have used the imprecision of in ternational law as a read y-made tool for furthering their ends. They have done so by advancing unsupported claims to legal rights and by distorting the meaning of generally recognized rules of international law" [14].

Morgenthau emphasizes the role that power plays in legal decisionmaking, and the manipulative use of legal rules in justifying the power-based decisions of governments. Similarly, Acheson analyzes part icularly the Cuba n quarantine which was, after the fact, purportedly justified by scholars and politicians as an appropriate use of i nternational law. Acheson however, disagrees with these purported justifications, and instead argues that: "The power, position and prestige of the United States had been challenged by another state; and law simply does not deal with such questions of ultimate power..." [13] (p. 108). Acheson-like appeals to power as a motivating force are frequently acknowledged and asserted in the writings of legal realists.

Another key component of the legal realist analysis of legal decisionmaking is the assertion that judicial decisionmaking is largely fact-cen tered. That is to say that the particular facts of an individual case play a larger role in judicial decisionmaking than formalism permits. According to this premise, the individual policy considerations, including the social sciences, are (consciously or unconsciously) examined by judges who decide a case based on the facts-at-hand, as opposed to the rule of law [10] (pp. 184-185). Former Justice of the Supreme Court of the United States, Louis Brandeis, for example, argues that judges should consider good social policy when making decisions [9] (pp. 35-36). Aside from his tenure on the Supreme Court, Brandeis is perhaps most famous for his then-unique style of argumentation as a lawyer. Brandeis would frequently present judges with lengthy briefs filled with sociological data analyzing the potential impact of the judges' decisions on society, or groups of people. [10] (pp. 184-185). Such briefs have since become referred to as Brandeis Briefs, and are used with everincreasing popularity by lawyers in difficult cases [10] (pp. 184-185). Perhaps the most famous utilization of a Brandeis Brief was in the paradigm case of Brown v. Board of Education, [16] wherein the plaintiff submitted an elaborate bri ef containing data regarding how school segregation psychologically harms minority children (in support of an equal protection argument). Due, in part, to this elaborate argument the Supreme Court of the United States held that the public school system should be desegregated [9] (pp. 35-36). The realists frequently appeal to the social sciences, as well as to principles such as power, morality, and policy in their examinations of how legal decisions are or should be made.

\section{(B) Indeterminacy of Laws}

The second tenet of legal realism, the assertion that laws are indeterminate, is clo sely related to the first. The realist critique of formalism attacks the formalist premises that legal rules alwa ys provide a $\mathrm{c}$ lear answer to cases, and $\mathrm{t}$ hat judicial decisionmaking is accomplished simply by a judge finding the correct rule to apply. Realists contend that rules do not always have a determinate meaning and neutral application as formalists allege. In some cases, such as determining whether someone timely renews her driver's license under the laws of the Commonwealth of Virginia, the rule and application are typically determinate. However, in more difficult cases, the rules a re rarely as determinate. Take the meaning of such phrases as the Eighth Amendment's prohibition on "cruel and unusual" punishment, or the "equal protection" clause, both of which are perennially subject to debate as to scope and meaning.

Legal philosopher H.L.A. Hart, in his classic work The Concept of Law, introduces the term open texture of the law [17]. Although Hart is a p ositivist, his analysis addresses realist ideas. Hart refers to "legal realism" as "rule ske pticism" in his critique [17]. Hart claims that rules have open texture, which means that the words used to write rules have a core meaning, and outside of that core meaning, there a re only a li mited number of reason able options for interpretation [17] (pp. 124-147). The realists, however, typically take things a step further by claiming that judges can manipulate the rules to mean whatever they think the rules should mean in a given situation by appealing to policy, power, the social sciences, morality, or any co mbination of the precedi ng. Hart's positivist view incorporates open texture, a more conservative view than legal realism's skeptical contentions.

The realists' an ti-formalistic contentions are so metimes referred to as the indeterminacy thesis. The in determinacy thesis manifests in the dissenting opinion of the famous tort case, Palsgraf v. Long Island Railroad [18]. In Palsgraf, the plaintiff was a railroad passenger who claimed the railroad employee was negligent in assisting another passenger, and consequently, the other passenger dropped a pac kage containing fireworks. The fi reworks exploded and in jured the plaintiff. The Palsgraf majority determined that the railroad employee was not liable to the plaintiff for negligence. Judge Andrew's dissenting opinion in Palsgraf examined, among other things, the indeterminacy of the concept of prox imate cause [18] (p. 347). Judge Andrews explained: "What we do mean by the word 'proximate' is that because of convenience, of public policy, of a rough sense of justice, the law arbitrarily declines to trace a series of events beyond a ce rtain point. This is not logic. It is practical p olitics" [18] (p. 352). Judge Andrews's designation of the meaning of "proximate" within the negli gence analysis signifies the judicial realization of the indeterminacy of this term in the law. Proximate cause is one of the requirements for a showing of negligence in almost any jurisdiction of the United States. The admission by Judge Andrews that a finding of proximate 
cause by a court is arbitra ry gives rise to the inference that any negligence action could be decided either way depending on the judge's arbitrary reading of this element. Or, as some legal realists may assert, depending on what mood the judge is in.

The indeterminacy thesis and realist an alysis of legal decisionmaking have several parallels within Nietzsche's thought. These parallels and how Nietzschean philosophy may be used a $\mathrm{s}$ a justificatory mechanism for legal realism are examined in the following section.

\section{PART III: A NIETZSCHEAN JUSTIFICATION OF LEGAL REALISM}

This section addresses how Nietzsche's philosophy may be used as a justification of legal realism. Nietzsche's philosophy may be utilized to create coherence to what appears to be an incoherent theory of legal realism. Due to the seeming incoherence of legal realism, some commentators refuse to consider legal realism a theory, but instead consider it only the "lawyer's perspective" [9] (p. 35). Providing a full expository necessary to convincingly make the cas e that Nietzsche's philosophy is the appropriate justification of legal realism is outside the scope of this essay. Instead, this essay is meant to introduce Nietzschean thought as a ju stification of legal realism and present several parallels between the thought of Nietzsche and the legal realists. For th e purpose of this experiment in justification, this essay will ignore entirely the question of whether legal realism needs a justification, but rather assumes that it does. This section first discusses certain $p$ arallels between Nietzsche's will to power and legal realism. It then turns to the $\mathrm{u}$ tilization of Nietzsche's overman and master-slave moralities as justifications of realist lawmakers. Finally, it considers Nietzsche's conception of the state as formalistic jurisprudence.

\section{(A) Will To Power as a Justification of Legal Realism}

Nietzsche asserts that power is the fundamental principle of the universe; a princi ple that permeates nature, justice, humanity, society, and the state. Nietzsche also discusses the role that power plays in motivating political decisions as well as the role power plays in the implementation of a legal system that imposes punishment and reward [3] (p. 396). As a fundamental principle, power provides a justification of legal decisionmaking. Many legal realists also appeal to an underpinning principle of power. The power construct of realism is absorbed by the more-universal power construct: Nietzsche's will to power. In other words, the power construct of legal realism is a symptom of the more comprehensive power construct that Nietzsche describes. Such authors as Dean Acheson and Hans Morgenthau, who identify power as the underlying motivator of legal decisionmaking, write on specific instances of the broader construct that Nietzsche describes in his doctrine of will to power. The powermotivations of the Cuban quarantine that Acheson discusses, and the manipulation of international law via power politics that Morgenthau analyzes, are merely symptoms of the more comprehensive Nietzschean will to power $[13,14]$. As a fundamental principle, the will to power underlies all decisionmaking, including legal decisionmaking.

Power, however, is not the only principle to which legal realists refer, but realists also discuss (among other things): appeals to morality, policy, and the social sciences in their diverse analyses. Nietzsche's will to power also entails these variant views. The diverse views of legal realists are assertions of power by the various authors who adhere to individualized interpretative methodologies. Realist authors, such as Oliver Wendell Holmes, Felix Cohen, Louis Brandeis, Jerome Frank, Rosc oe Pound, Karl Llewellyn, John Dewey, Walter Cook, and many other notable authors, appeal to different methodologies of decisionmaking via their individualized assessments of values [19]. The various views of the realists are mani festations of expressions of power by the authors, who adhere to their individualized views. Although realist views are nuanced, they share the common anti-formalistic thread of Nietzschean thought.

The Nietzschean movement away from previous fundamental principles and "great philosophies" is mirrored by the realist movement away fro $m$ rules as fun damental determinants of law and the formalistic system [4] (pp. 10-11). As Nietzsche questions the motives, intentions, and drives of philosophers who write $\mathrm{g}$ reat theories, so $\mathrm{d}$ o the realists question the motives, intentions, and drives of judges who come to decisions. The skepticism of Nietzsche and the realists towards the pre-existing structure is appa rent also in their mutual attention to other factors which impact the decisions made by philosophers and $\mathrm{j}$ udges. These fact ors include: power, policy, and the morality of the individual who makes the decision, or who writes the philosophy. Nietzsche considers these factors in the context of "social judgment" a means of increasing the power of the st ate [3] (p. 385). Nietzsche even goes so far as to say that these tools of social judgment are utilized by a court of law in order to justify the punishment of criminals [3] (p. 403). The mutual skepticism as to the rules of law and the manipulative use of such rules are shared themes by Nietzsche and the legal realists.

The realist view that a judge should make decisions based on principles outside of the rule of law (e.g., policy, morality, social sciences, etc.) is similar to Nietzsche's vi ew that an individual should derive his own interpretations of the formula instead of abiding by a ne utral formula of the herd. The will to power requires that individuals, including lawmakers, derive their own interpretations based on considerations other than the pre-existing ideologies, that is to say, other than the legal rules [3] (p. 403). The will to power, an all-pervasive doctrine, encapsulates the necessity of appealing to individual internalities and realized externalities in making decisions, just as the legal realists contend that this is what courts in fact do, and sometimes should do, when coming to a legal decision.

The current division of labor between such vocations as teachers and lawmakers, which Nietzsche contends prevents any single person from accepting all blame, acts as a shield to those who would question a jud ge's application of the rules [3] (pp. 383-384). The division of legal labor via sepa- 
ration of powers (e.g., executive, legislative, and judicial branches) permits a multitude of officials to engage in the process of law creation and application, but simultaneously exculpates any sin gle lawmaker from sole responsibility. Although one purpose of the separation of powers may be to assuage the potential for absolute power, the legal system is divided and responsibilities diverse enough to allow for individualized expressions of power within the existing formulaic system. The indeterminate rules are manipulated by those in power to suit their needs and interpreted by the whims of the lawgivers, according to both realist an $d$ Nietzschean thought. The will to power does in this way justify the legal realist contention that legal decisions are based in power considerations other than mechanically applied, formalistic rules.

\section{(B) The Overman \& Master-Slave Moralities as Justifica- tions of Legal Realism}

The Nietzschean overman and master-slave moralities have several parallels to leg al realist jurisprudence. The overman, as the ideal individual who maneuvers beyond previous ideologies, and develops his own sense of morality is the properly-functioning realist lawmaker. A lawmaker must move beyond the rules set forth by prior lawmakers just as the overman must move beyond the philosophies set forth previously. In so doing, the lawmaker as an overm an must develop his or her own value-system within which to make determinations as to either what laws will be leg islated (the legislator-overman), how those laws should be judicially interpreted (the ju dicial-overman), or how th ose laws are enforced (the executive-overman). The following discussion addresses each in turn.

The legislator, from a Nietzs chean perspective, is a servant of the state. As a servant to the master of the state, the legislator must overcome the servant status by moving beyond such primitive notions as patriotism, nationalism, and duty-to-state [3] (p. 383). The legislator-overman must move beyond these pre-existing moral ideologies, develop his own value-system, and implement this system in his lawmaking. The Nietzschean assertion that everything a lawmaker does while in service of his state is "contrary to his nature," and thus is not an act of freedom, can be overcome by the legislator-overman through developing an i ndividualized valuesystem [3] (p. 383). This value-system may include, as the legal realists a dvocate, appeals to the principles of power, policy, the social sciences, morality, or any combination of the preceding. Both the realists and Nietzs che contend that this value-system should not be based on formalistic, preexisting rules and methods of prior lawmakers and philosophers, but rather should be an i ndividual interpretation of these pre-existing formulas.

The judge, as a servant of the state, is also subject to the master morality of that state. The judge is in a unique position of power, however, insofar as the judge is allocated by law a limited amount of discretion in deciding cases. Within this judicial discretion, the judge has the power to become the judicial-overman. The judicial-overman is represented by the realist judge who identifies the indeterminacy of laws, develops a value-system to interpret those laws, and comes to decisions based on that value system. Although there are formulas in place that a judge must work within, Nietzsche asserts that the overman should interpret these formulas in order to create a new system of values. The interpretation of these formulas is personal, for Nietzsche, and may be utilized as a $\mathrm{m}$ eans of overcoming the prior structure [3] (p. 403). The pre-existing formulas for the judge include existing laws su ch as co nstitutions, legislation, administrative rules, and prior judicial decisions. The judicial-overman may also desire to take into account society's sense of justice, and what the populace will accept without revolt. By interpreting the formula by use of policy, social sciences, ethics, or even power, the judicial-overman will move beyond the slavemorality of the state.

The executive is often charged with the proper enforcement of laws, and is particularly influential in actions involving foreign governments. In making decisions, the executive may similarly be considered a slave to the master-morality of the state if he permits himself to be bound solely by the rule of law. In making decisions about how to act towards and react to other states, the executive-overman must see beyond the rule of law, determine his own value-system, and initiate action based on that value system. Dean Acheson and Hans Morgenthau both analyze political action in the context of international relations, and conclude that political action is based on power, as o pposed to law [13, 14]. Acheson's analysis of the Cuban quarantine provides a vivid illustration of the executive-overman in action. Amidst this crisis, the government of the United States initiates a blockade to prevent military equipment and weapons from reaching Cuba [20]. Although there is no sound basis under international law for this blockade, and it is technically an act of war under international law, President Kennedy proceeds to quarantine Cuba [20]. Acheson describes this event as a decision made due to power politics, as opposed to a decision made under the rule of law, and criticizes other scholars for their subsequent attempts to justify the quarantine under international law [13]. Even though Kennedy's decision to quarantine Cuba violates international law, Acheson nevertheless believes it is the right decision [13]. Acheson, in other words, believes that Kennedy's refusal to abide by the formalistic regime, and his decision to act in accordance with an independent value-system, is the right thing to do [13]. During the Cuban quarantine, President Kennedy acts as an executive-overman by decisively preserving the power of the United States $d$ espite that a fo rmalistic reading of $p$ reexisting legal ideologies (i.e., international law) would have prohibited his action.

The executive-overman, judicial-overman, and legislatoroverman are properly funct ioning realist lawm akers who examine more than just the rule of law wh en making legal determinations. Consideration of moving beyond preexisting formulas and dichotomies is not unique to Nietzsche or the legal realists, but is also apparent in the literature of many postmodern thinkers including Michel Foucault, who wrote frequently on the meaning of power [21] (pp. 3-8). The striking similarities between the thought of Nietzsche 
and the legal realists, however, provide a mechanism by which the Nietzschean ideal of the overman may be implemented as a justification of the legal decisionmaking process proposed and described by the legal realists.

\section{(C) Nietzschean State as Realist Formalism}

The legal realist attack on the previous formalistic regime is paramount to Nietzsche's critique of the state as a master that imposes morality on its slave populace. As the state requires strict adherence to its rules and principles, including nationalism, patriotism, and duty-to-state [3] (pp. 382-383), so does the formalistic regime require adherence to the rule of law without employing individualized value assessments [10] (pp. 178-180). For the formalist, a judge's only responsibilities are discovering the appropriate rule of law in coming to a decision, and using logic to deduct the result of the case. The realists, on the other hand, assert that a judge uses fact-specific inquiries to determine the appropriate res ult in cases. These fact-specific inqui ries involve a judge doi ng more than just following the regime of rules, but rather require a judge to analyze and interpret the rules. In analyzing and interpreting the rules, the judge implements an independent value-system which may be c omposed of power, policy, social science, morality, or any combination of the preceding.

The Nietzschean state holistically provides a sh ield to lawgivers who utilize the state's rules by virtue of the formalistic and state-delegated method of applying rules without interpretative value analyses. According to Nietzsche, the lawgivers are exempt from independent blame, but instead the blame is a ttributed to the state in the guise of national necessity and duty-to-state [3] (pp. 383-384). The strictly rule-applying judge is a symptom of formalism, which similarly requires the strict-application of law without independent value-judgments. The realist judge, on the other hand, is more akin to the Nietzschean individual who interprets and analyzes the pre-existing rules, and thus is not exempt from blame for the personal decisions that the judge makes based on his or her independent value analysis. This independent value analysis permits the realist judge to escape the slavemorality imposed by the state, and to apply the law in the manner that satisfies the judge's independent system of values.

Nietzsche's will to power, if utilized properly by the realist judge, will result in the realist judge escaping the herd mentality. The herd mentality in state contexts involves what Nietzsche refers to as "s ocial judgment" - a conce ption that includes appeals to "common rules and valuations," that are used to manipulatively justify state action [3] (p. 385). The herd, in the context of the Nietzschean state, refers to the populace of a state (including state-actors). One will escape the herd mentality by moving beyond the common rules, and interpreting the rules in a manner consistent with individual value determinations. The realist judge is capable of making individual determinations in lig ht of the realist tenet that laws are indeterminate (they do not provide neutral answers to all legal issues that enter a court of law). The realist judge, through independent valuations, can escape the herd and avoid social judgment. The Nietzschean conception of the state is the formalistic regime that realists attacked, despised, and moved beyond.

\section{PART IV: CONCLUSION}

Nietzsche's philosophy may be used as a justification of the seemingly incoherent positions of legal realists. Ev en though Nietzsche was septical of p hilosophies containing fundamental principles, his will to power may nevertheless be viewed as a fundamental principle that justifies the diverse views of realist author $\mathrm{s}$ and realist lawm akers. The overman provides an ideal that lawmakers can strive for in order to overcome the slave mentality imposed by the state. By embracing the overman, lawmakers will move beyond the previous formalistic regime of prior great philosophies. The Nietzschean conception of the state is akin to the realist conception of form alism. According to both Nietzsche a nd the legal realists, lawmakers should move beyond formalism to become independent creators of value systems.

\section{CONFLICT OF INTERSEST}

The authors confirm that this article content has no conflicts of interest.

\section{ACKNOWLEDGEMENT}

None declared.

\section{REFERENCES}

[1] Schacht R, Nietzsche AR. Eds. in A Companion to the Philosophers. Malden Massachusetts: Blackwell Publis hing 2001; pp. 414-21.

[2] Scott CE, Nietzsche CS, Sch roeder W. Eds. in A Companion to Continental Philosophy. Malden, Massachusetts: Blackwell Publishing 1991, pp. 153-61.

[3] Nietzsche F. Will to Power. NY: Random House Publishing 1968.

[4] Nietzsche F. Beyond Good and Evil: Prelude to a Philosophy of the Future. Zimmern H, Ed. NY: The Macmillan Company Press, 1907.

[5] Nietzsche F. On the Geneal ogy of Morals and Ecce Ho mo. Kaufmann W, Ed. U.S.A: Vintage Books Edition 1989.

[6] Nietzsche F, Kau fmann W. Ed., The Portable Nietzsche. NY: Viking Penguin Inc 1982.

[7] Holmes Jr. O W. The Co mmon Law. Chesterland, Ohio: The General Bookbinding Co. 1881.

[8] Holmes Jr. OW. The Path of L aw, in Fisher III WW. (Ed.) (1993) in American Legal Realism. Oxford, U.K: Oxford University Press 1897; pp. 15-24.

[9] Murphy JG, Coleman J. Philos ophy of L aw: An Introduction to Jurisprudence, Revised ed. Boulder, Co: Westview Press 1990.

[10] Bix B. Jurisprudence: Theory and Context, $3^{\text {rd }}$ ed., Durham, NC: Carolina Academic Press 2004.

[11] Pound R. Mechanical Jurisprudence, 8 Columbia Law Review 605, 1908.

[12] Cohen F. Transcendental Nonsense and the Functional Approach, Fisher III WW, Ed. (1993) American Legal Realism, Oxford, U.K: Oxford University Press 1935; pp. 220-1.

[13] Acheson D. Remarks in Beck RJ, Ed. (1996), International Rules: Approaches from International Law and Internation al Relations. Oxford, U.K: Oxford University Press 1963; pp. 107-108.

[14] Morgenthau H. P olitics Among Nations: The Struggle for Power and Peace. NY: Publishing, 1948.

[15] Beck RJ. Ed. International Rules: Approaches from International Law and International Relations. Oxford, U.K: Oxford University Press 1996.

[16] Brown v. Board of Education of Topeka, 347 U.S. 483 (1954). 
[17] Hart HLA. The Concept of Law, $2^{\text {nd }}$ ed. Oxf ord, U.K: Oxf ord University Press 1997.

[18] Palsgraf v. Long Island Railroad Co., 248 N.Y. 339, 162 N.E. 99 (N.Y. 1928).

[19] Fisher III WW. Ed. American Legal Realism. Oxford, U.K: Oxford University Press 1993.
[20] The Naval Quarantine of Cuba, Report on the Naval Q uarantine of Cuba, Operational Archives Bran ch, Post 46 Command File, Box 10, Washington, DC. Naval History \& Heritage Command 1962.

[21] Urbanski S. The Identity Ga me: Michel Foucault's DiscourseMediated Identity as an Effectiv e Tool for Achieving a NarrativeBased Ethic. Open Ethics J 2011; 5: 3-9.

Received: October 09, 2012

Revised: January 11, 2013

Accepted: January 14, 2013

(C) Keith William Diener; Licensee Bentham Open.

This is an open ac cess article licensed under the terms of the Creative Commons Attribution Non-Commercial License (http://creativecommons. org/licenses/ by-nc/3. 0/) which permits unrestricted, non-commercial use, distribution and reproduction in any medium, provided the work is properly cited. 